Jurnal Widya Sastra Pendidikan Agama Hindu, Vol 4, No. 2, 2022

ISSN: 2656-7466

\title{
IMPLEMENTASI NILAI-NILAI KARAKTER YANG TERDAPAT PADA GEGURITAN NI DYAH TANTRI SISWA KELAS XI AKUNTANSI SMK TI BALI GLOBAL SINGARAJA TAHUN AJARAN 2020/2021 \\ Oleh
}

Ni Kadek Widiasih

Email: dekwidya9@gmail.com

I Nengah Dwi Endra Suanthara

dwisuanthara@gmail.com

\section{ABSTRAK}

Karakter adalah sifat batin yang mempengaruhi segenap pikiran, perilaku, budi pekerti siswa. Radikalisme dikalangan generasi muda termasuk siswa dapat disebabkan oleh lemahnya karakter yang dimilikinya, oleh karenanya perlu diteliti. Penelitian ini bertujuan untuk mengkaji nilai-nilai karakter yang terdapat pada geguritan Ni Dyah Tantri dan implementasinya pada Siswa SMK TI Bali Global Singaraja. Untuk memperkuat pembahasan terhadap tujuan di atas digunakan kajian teori. Dalam memecahkan masalahh digunakan beberapa metode yaitu: penelitian dirancang dengan penelitian kualitatif yang berlaku pada SMK TI Bali Global Singaraja, metode penentuan informan digunakan populasi studi atau meneliti seluruh siswa dalam kelas tersebut, metode pengumpulan data digunakan kuisioner, wawancara, obsevasi, dan pencatatan dokumen, metode uji keabsahan data digunakan trianggulasi dan analisis data digunakan deskriptif kualitatif yang menggunakan skor atau angka sebagai dasar untuk menentukan makna kualitatif. Hasil analisis diperoleh bahwa nilai karakter yang terdapat dalam geguritan Ni Dyah Tantri ada tujuh karakter, masing-masing dengan rincian skor implementas yaitui; nilai karakter cinta kasih 92,75\% (Sangat Baik), nilai karakter disiplin dan kesetiaan 87,33\% (Sangat Baik), nilai karakter bersahabat dan komunikatif 71,5\% (Cukup), nilai karakter kecerdasan 90, 54\% (Sangat Baik), nilai karakter demokratis dan keiklasan 81,75\% (Baik), nilai karakter ketangguhan dan kerja keras 92,66\% (Sangat Baik), dan nilai karakter patriotik dan cinta damai serta toleransi 96\% (Sangat Baik). Hasil penelitian direkomendasikan kepada para pendidik terutama guru di SMK TI Bali Global Singaraja dan orang tua Siswa dapat mentransfer nilai-nilai karakter dalam geguritan Ni Dyah Tantri lebih baik lagi untuk menunjang capaian lulusan yang berkualitas.

Kata kunci: Nilai Karakter, Geguritan Ni Dyah Tantri 
Jurnal Widya Sastra Pendidikan Agama Hindu, Vol 4, No. 2, 2022

ISSN: 2656-7466

\title{
IMPLEMENTASI NILAI-NILAI KARAKTER YANG TERDAPAT PADA GEGURITAN NI DYAH TANTRI SISWA KELAS XI AKUNTANSI SMK TI BALI GLOBAL SINGARAJA TAHUN AJARAN 2020/2021 Oleh
}

Ni Kadek Widiasih

Email: dekwidya9@gmail.com

I Nengah Dwi Endra Suanthara dwisuanthara@gmail.com

\begin{abstract}
Character is an inner trait that affects all thoughts, behavior, and character of students. Radicalism among the younger generation, including students, can be caused by the weakness of its character, therefore it needs to be investigated. This study aims to examine the character values contained in Ni Dyah Tantri's geguritan and their implementation in SMK TI Bali Global Singaraja students. To strengthen the discussion of the above objectives, a theoretical study was used. In solving the problem, several methods were used, namely: the research was designed with qualitative research that applied to the SMK TI Bali Global Singaraja, the method of determining the informants was used by the study population or researching all students in the class, the data collection methods used questionnaires, interviews, observations, and document recording, the data validity test method used triangulation and descriptive qualitative data analysis used scores or numbers as the basis for determining the qualitative meaning. The results of the analysis showed that the character values contained in Ni Dyah Tantri's geguritan were seven characters, each with details of implementation scores, namely; love character value $92.75 \%$ (Very Good), discipline and loyalty character value $87.33 \%$ (Very Good), friendly and communicative character value $71.5 \%$ (Enough), intelligence character value $90,54 \%$ (Very Good ), the value of democratic character and sincerity is $81.75 \%$ (Good), the character value of toughness and hard work was $92.66 \%$ (Very Good), and the value of patriotic character and love of peace and tolerance was $96 \%$ (Very Good). The results of the study were recommended to educators, especially teachers at SMK TI Bali Global Singaraja and parents. Students can transfer character values in Ni Dyah Tantri's geguritan better to support the achievement of quality
\end{abstract}

Keywords: Character Value, Geguritan Ni Dyah Tantri 
Jurnal Widya Sastra Pendidikan Agama Hindu, Vol 4, No. 2, 2022

ISSN: 2656-7466

\section{PENDAHULUAN}

Kegiatan olah sastra lama di Bali yang berbentuk prosa maupun puisi sampai sekarang masih hidup dan berkembang. Salah satu karya sastra yang akrab di kalangan masyarakat Bali yaitu prosa Bali tradisional, yang berupa satua. Diantara sekian banyak satua yang ada di Bali, Geguritan Ni Dyah Tantri karya I Made Pasek dipilih dalam penelitian ini karena memiliki kelebihan yang terletak pada alur cerita yang banyak memberikan nasehat yang berguna dalam kehidupan bermasyarakat utamanya di era modernitas seperti sekarang ini. Fenomena terkait perilaku masyarakat akhir-akhir in lebih akrab disebut dengan degradasi moral. Lunturnya nilai nilai luhur dalam masyarakat, termasuk nilai karakter disebabkan masyarakat Indonesia kurang gemar membaca buku, salah satunya membaca karya sastra. Keberadaan Geguritan Ni Dyah Tantri yang sudah akrab dikalangan masyarakat utamanya generasi muda Bali diharapkan dapat menjadi media pembelajaran sebagai pembentuk karakter yang luhur. Secara etimologi Geguritan berasal dari kata gurit, yang artinya gubah, karang, sadur. Geguritan berarti sanduran cerita yang terbentuk tembang (kamus Bahasa Bali, 1978:223). Mengenai geguritan ini, Made Djendra berpendapat bahwa geguritan adalah karya sastra yang dibangun oleh pupuh-pupuh dan diikat oleh aturan padalingsa (1974:9). Oleh karena itu dapat pula dikatakan bahwa gegurtian adalah produk karya sastra tradisional (klasik) yang mempunyai sistem konvensi sastra cukup ketat. Dengan demikian, kalau membaca sastra geguritan tidaklah dapat seperti membaca hasil karya prosa. Geguritan merupakan salah satu jenis karya sastra. Karya sastra yang baik adalah karya sastra yang didalamnya terkandung aspek sastra, seperti aspek intrinsik dan aspek ekstrinsik. Aspek intrinsik adalah aspek dalam karya sastra sastra yang mempengaruhi penciptaan karya sastra itu sendiri dalam (Esten, 1984:20), sedangkan aspek ekstrinsik adalah aspek lain dari karya sastra yang juga mempengaruhi penciptaan karya sastra. Kurang lebih pada abad ke-18, ketika sekolah atau pendidikan formal belum maju seperti dewasa sekarang ini maka masyarakat khususnya di Bali dalam memenuhi kebutuhannya akan pendidikan tattwa, susila dan agama sering memanfaatkan karya sastra sebagai medianya melalui pesantian-pesantian atau kelompok-kelompok masyarakat pecinta sastra (geguritan), sehingga muncul istilah malajah sambilang megending, megending sambilang melajah yang kini dipakai sebagai salah satu metode pembelajaran. Disamping itu geguritan mempunyai peranan penting dalam pembinaan moral dan spiritual masyarakat Bali, dalam rangka mengembangnkan kesenian khususnya dan kebudayaan Bali pada umumya (Agastia: 1980:25). Karya sastra geguritan banyak tersebar di Bali. Begitu juga Geguritan Ni Dyah Tantri yang cukup populer dan sudah banyak dikenal oleh masyarakat Bali, baik dikalangan anak-anak, kaum muda-mudi, maupun dikalangan orang tua. Tetapi nilai yang terkandung dalam geguritan Ni Dyah Tantri tersebut kurang diketahui secara luas oleh masyarakat. Karena Geguritan Ni Dyah Tantri yang telah diciptakan oleh pengarangnya sebagai hasil karya sastra, bukan saja berfungsi sebagai hiburan tetapi mengandung nilai-nilai seperti ajaran agama, etika dan sebagainya yang berfungsi bagi kehidupan.

Fenomena yang nampak dewasa ini khususnya dalam kehidupan berbangsa dan bernegara adalah banyaknya kelompok-kelompok tertentu yang memanfaatkan Agama sebagai "topeng" untuk menggerakan massa berbuat anarsis. Banyak pula oknum-oknum tertentu yang melecehkan agamanya sendiri ataupun Agama orang lain. Masalah seperti ini dapat menimbulkan rapuhnya nilai kerukunan beragama. Negara Indonesia adalah negara yang multi etnis, agama suku, budaya dan lain-lain. Jika kerukunan multi etnis tidak bisa terjaga dengan baik maka Negara Indonesia akan 
bisa terbawa arus perpecahan. Demikian juga halnya kepada para generasi muda termasuk siswa dewasa ini banyak terjadi sikap dan perilaku mereka yang melanggar norma masyarakat. Tawuran antarpelajar muncul di beberapa daerah. Perilaku siswa yang cenderung melanggar aturan seperti aksi corat-coret pada pakaian seragam sekolah dengan berbagai tulisan yang berwarna warni disaat pengumuman hasil ujian akhir. Salah satu faktor penyebab munculnya sikap dan perilaku menyimpang atau melanggar terhadap norma masyarakat tersebut karena belum dipahaminya nilai-nilai agama dan belum diimplementasikan dalam tatanan kehidupan bermasyarakat, berbangsa dan bernegara. Kondisi seperti tersebut memungkinkan dapat tersebar di seluruh plosok tanah air termasuk di Bali. Agama Hindu merupakan agama tertua di Indonesia tentu memiliki nilai-nilai karakter yang sangat banyak dan mampu memberikan tuntunan sikap dan perilaku yang baik dalam kehidupan sehari-hari. Salah satunya adalah nilai agama yang terdapat pada Geguritan Ni Dyah Tantri. Apabila nilai karakter yang terkandung dalam Geguritan Ni Dyah Tantri tersebut dapat dipahami dan dierapkan dalam kehidupan sehari-hari diduga kerusakan inter dan antar beragama dapat tercapai.

Atas dasar analisa tersebut maka perlu diketahui nilai karakter yang terdapat dalam Geguritan Ni Dyah Tantri dan implementasi pada Siswa Kelas XI Akuntansi SMK TI Bali Global Singaraja. Siswa adalah generasi muda yang menjadi tulang pupnggung bangsa, perlu mendapat prioritas pendidikan karakter.

\section{METODE PENELITIAN}

Penelitian ini adalah penelitian kualitatif yang menggunakan angka atau bilangan sebagai dasar dalam menganalisis makna karakter yang diimplementasikan oleh siswa. Untuk memperoleh nilai-nilai karakter dalam geguritan Ni Dyah Tantri digunakan metode pencatatan dokumen berdasarkan teori hermeneutika. Metode penentuan informan digunakan studi populasi yaitu meneliti semua siswa kelas XI Akuntansi SMKTI Bali Global Singaraja. Metode pengumpulan data yang digunakan adalah: kuesioner, wawancara, observasi, pencatatan dokumen. Metode keabsahan data digunakan tri anggulasi dan analisis data digunakan deskriptif kualitatif.

\section{HASIL DAN PEMBAHASAN}

Dari hasil analisis diperoleh bahwa nilai karakter yang terdapat pada geguritan Ni Dyah Tantri adalah: 1) cinta kasih, 2) disiplin dan kesetiaan, 3) bersahabat dan komunikatif, 4) kecerdasan, 5) demokratis dan keiklasan, 6) ketangguhan dan kerja, 7) patriotik dan cinta damai serta toleransi. Sedangkan implementasi nilai karakter tersebutsecara klasikan ditemukan sebesar 85, 11\% (sangat baik). Namun dilihat dari implementasi untuk masing-masing aspek diperoleh hasil sebagai derikut.

\section{Karakter cinta kasih}

Karakter cinta kasih, dalam geguritan Ni Dyah Tantri telah diterapkan dengan sangat baik oleh masing-masing siswa kelas XI Akuntansi SMK TI Bali Global Singaraja dalam keseharian di kelasnya. Hal ini ditunjukkan dengan nilai karakter cinta kasih yang diimplementasikan oleh siswa sebesar 92,75\%. Dari hasil wawancara dengan siswa yang bersangkutan terkait dengan bagaimana mereka mengimplementasikan nilai-nilai karakter tersebut, sebagian besar mereka merespon bahwa cinta kasih adalah sikap yang sudah menjadi budaya pergaulan mereka baik di sekolah maupun di luar sekolah termasuk di dalam keluarga. Banyak model implementasi yang mereka lakukan dengan sangat beragam diantara mereka. Tetapi 
makna yang terkandung dalam aktivitas atau implementasi adalah sama yaitu cinta kasih. Sikap cinta kasih ini di dalam sekolah mereka lakukan dengan berbagai variasi antara lain; mencintai dan mengasihi satu sama lain tanpa membeda-bedakan jenis kelamin tapi ini terwujud dalam kontek pertemanan atau persahabatan. Cinta dalam kontek "berpacaran" cenderung tidak direspon oleh mereka. Sikap cinta kasih juga diterapkan dengan cara saling mengingatkan hak dan kewajiban dalam melaksankan tugas pelajaran, kegiatan kokurikuler termasuk tugas piket kelas dan sejenisnya. Implementasi sikap seperti ini merupakan faktor penting yang sangat positif dan harus mendapat perhatian oleh guru dan orang tua mereka. Implemntasi sikap cinta kasih juga nampak dilaksanakan oleh mereka di luar jam pelajaran atau di luar kelas. Model penerapannya dalam kegiatan Pramuka dimana diantara mereka saling membantu dalam kegiatan kelompok atau antar kelompok. Bentuk riil implementasi cinta kasih adalah menolong teman mereka jika dalam kegiatan tersebut ada yang sakit atau kelelahan maka mereka kompak memberikan bantuan pertolongan pertama sampai mengantar UKS atau rumah sakit jika diperlukan. Penerapan sikap cinta kasih juga dilaksanakan di dalam masyarakat dimana siswa tersebut berdomisili/bertempat tinggal. Bentuk implementasinya kerjasama, gotong royong pada tempat-tempat umum seperti di Pura, di jalan desa, dibalai masyarakat. Hanya saja implentasi ini tidak tertuju antar orang ke orang tapi cita kasih terhadap lingkungan. Model lain juga banyak variasi implementasinya yaitu diterapkan dalam organisasi sosial kepemudaan, pelajar, keagamaan (sekaha truna/Truna Pesaren). Sedangkan di dalam keluarga bentuk sikap cinta kasih diimplementasikan antar anggota keluarga dimana mereka sangat menyayangi anggota keluarga mereka. Fenomena sebagai hasil penelitian seperti di atas ternyata sesuai dengan teori belajar Humanistik Huberman yang ditulis oleh Ratna Syifa'a Rachmahana (2008) pada prinsipnya dinyatakan bahwa belajar terjadi ketika seseorang melakukan interaksi dengan lingkungannya. Lingkungan belajar yang dimaksud Haberman adalah lingkungan alam dan lingkungan sosial. Keduanya merupakan lingkungan yang tidak bisa dipisahkan dalam kehidupan manusia. Teori belajar dari Habermas yang menelurkan hasil pemikiran berupa klasifikasi tipe belajar seseorang, yaitu: technical Learning adalah teknik belajar di mana seseorang berinteraksi dengan sekitarnya, terutama lingkungan alam, secara benar. Mereka belajar tentang pengetahuan dan keterampilan apa yang dibutuhkan agar mereka bisa mengelola lingkungan alam secara baik dan juga benar. Practical Learning adalah teknik dimana seseorang mampu berinteraksi dengan lingkungan sosial. Mereka belajar bagaimana caranya berinteraksi dengan manusia lain secara harmonis. Interaksi yang terjadi secara benar pada individu yang belajar dengan lingkungan alam akan tampak dari relevansinya dengan kepentingan manusia. Dilihat dari teori belajar di atas ternyata implemntasi sikap cinta kasih adalah penerapan proses belajar non akademik yang dapat berkontribusi positif terhadap prestasi belajar terutama pada aspek sikap (afektif) dan perilaku (psychomotor). Hampir semua implementasi sikap cinta kasih di atas termasuk ke dalam tipe belajar technical learning dan practical learning, dimana siswa berinteraksi dengan lingkungan alam dan sosial.

\section{Karakter Disiplin dan Kesetiaan}

Karakter disiplin dan kesetiaan, nilai karakter disiplin dan kesetiaan dalam geguritan Ni Dyah Tantri telah diterapkan dengan sangat baik oleh masing-masing siswa kelas XI Akuntansi SMK TI Bali Global Singaraja dalam keseharian di kelasnya. $\mathrm{Hal}$ ini ditunjukkan dengan nilai karakter disiplin dan kesetiaan yang 
diimplementasikan oleh siswa sebesar 87,33\%. Karakter disiplin dan kesetiaan merupakan umum yang dimiliki oleh kebanyakan orang. Dari hasil wawancara dengan siswa terkait bagaimana mereka mengimplementasikan karakter tersebut dalam kehidupan di sekolah maupun di luar sekolah, mereka merespon bahwa karakter tersebut terlaksana tanpa perencanaan karena sudah menjadi hal sangat biasa bagi siswa. Karakter disiplin adalah kewajiban siswa untuk melaksankan karena tuntutan dari sekolah yang dilaksanakan oleh guru melalui penerapan tata tertib sekolah. Khusus karakter disiplin ada beberapa sikap siswa dalam mengimplementasikannya. Siswa yang memiliki sikap malas kurang perhatian dengan pendidikan merasa menerapkan karakter disiplin dengan rasa terpaksa. Tetapi siswa yang tekun rajin dan senang bersekolah merasa tidak beban dan sangat mendukung jika tata tertib diterapkan dengan tepat dan benar. Implementasi karakter disiplin menurut pendapat dari beberapa responden dirasa berat hanya dua atau tiga bulan di depan khusus mereka pada saat jadi siswa baru di SMK TI Bali Global. Selanjutnya beban itu terasa hilang dan mereka menerapkan disiplin sesuai dengan tata tertib sekolah. Dengan kesadaran mereka maka karakter ini diterapkan pada semua aspek kegiatan sekolah seperti berpakaian, masuk kelas, belajar di kelas, waktu istirahat termasuk dalam kegiatan kokurikuler dan upacara bendera. Sedangkan kesetiaan diimplementasikan dalam kegiatan sehari-hari di sekolah terhadap semua teman sekelas maupun teman lain di kelas lain termasuk guru dan pegawai serta warga sekolah yang lain. Bentuk implementasinya seperti: mengucapkan salam Om Swastyastu antar siswa dan anggota sekolah yang beragama Hindu, selamat pagi, siang dan sore, sesuai suasana pada saat itu. Saling bertegur sapa, dan menunjukkan rasa simpati dengan ekspresi wajah persahabatan. Saling tolong menolong dalam suatu kegiatan atau tugas tertentu yang diawali dengan komunikasi "minta tolong". Kata "minta tolong" dijadikan kunci bagi mereka dalam menjalin kesetiaan. Fakta hasil penelitian di atas merupakan penerapan dari teori hegemoni Gramsci yang ditulis (Ratna, 2005) pada prinsipnya dinyatakan bahwa hegemoni adalah sebagai suatu dominasi kekuasaan suatu kelas sosial atas kelas sosial lainnya, melalui kepemimpinan intelektual dan moral yang dibantu dengan dominasi atau penindasan, namun dilaksanakan secara halus yang ditujukan untuk menumbuhkan kesadaran moral, dimana seseorang disadarkan lebih dulu akan tujuan hegemoni itu. Setelah seseorang sadar, ia tidak akan merasa dihegemoni lagi melainkan dengan sadar melakukan hal tersebut dengan suka rela. Jadi implementasi sikap disiplin adalah penerapan teori hegemoni yang dilakukan oleh sekolah (kepala sekolah) melalui peraturan tata tertib sekolah. Sekolah bermaksud merubah sikap siswa yang cenderung melanggar norma dengan cara "memaksa" akan tetapi siswa tidak merasa dipaksa karena mereka telah menyadari bahwa berbuat baik adalah suatu kewajiban yang wajib dilakukan oleh para siswa.

\section{Karakter Bersahabat dan Komunikatif}

Karakter bersahabat dan komunikatif, nilai karakter bersahabat dan komunikatif dalam geguritan Ni Dyah Tantri telah diterapkan cukup oleh masing-masing siswa kelas XI Akuntansi SMK TI Bali Global Singaraja dalam keseharian di kelasnya. Hal ini ditunjukkan dengan nilai karakter bersahabat dan komunikatif yang diimplementasikan oleh siswa sebesar $71,5 \%$ (baik). Dari hasil wawancara dengan siswa yang bersangkutan terhadap bagaimana mereka menerapkan karakter bersahabat dan komunikatif, mereka merespon bahwa persahabatan itu adalah hakekat hidup sebagai manusia. Mereka menjelaskan bahwa persahabatan muncul dengan sendirinya tanpa harus direncanakan. Sebagian dari siswa mengaku semua sahabat mereka muncul dengan sendirinya tanpa dibuat atau direncanakan. Yang 
dipersoalkan adalah bagaimana harus menjaga sahabat agar tidak berubah menjadi musuh. Ini berarti implementasi karakter persahabatan dilaksanakan secara alami di sekolah maupun di luar sekolah. Ketika ditanyakan tentang mengimplementasikan agar bisa langgeng atau bertahan selamanya. Beberapa siswa menjelaskan bahwa factor kepribadian diri sendiri yang sangat menentukan. Jika ingin punya sahabat maka diri kita sendiri harus bersikap baik sama orang lain dan mampu mengontrol emosi serta mengendalikan diri sendiri agar tidak menyakiti orang lain. Terkait dengan karakter atau sikap komunikatif siswa menerapkan dalam pergaulan di sekolah yaitu saling bertegur sapa antara siswa, siswa dengan guru dan semua staf sekolah. Hal ini mereka sebut komunikasi verbal langsung. Sedangkan komunikasi tidak langsung lebih banyak melalui media sosial seperti WA, messenger, email, FB dan sejenisnya. Terlebih lebih disaat pandemic covid 19 ini lebih banyak dilakukan komunikasi melalui media elektronik. Disamping komunikasi dalam kontek persahabatan siswa juga menerapkan komunikasi akademik formal melalui daring terutama dalam proses pembelajaran yang dilakukan oleh guru.

\section{Karakter kecerdasan}

Karakter kecerdasan, nilai karakter kecerdasan dalam geguritan Ni Dyah Tantri telah diterapkan dengan sangat baik oleh masing-masing siswa kelas XI Akuntansi SMK TI Bali Global Singaraja dalam keseharian di kelasnya. Hal ini ditunjukkan dengan nilai karakter kecerdasan yang diimplementasikan oleh siswa sebesar $90,54 \%$ (sangat baik). Dari hasil wawancara dengan siswa berkenaan dengan implementasi karakter kecerdasan yang dilakukan di sekolah maupun di luar sekolah atau masyarakat mereka menjelaskan bahwa kecerdasan yang mereka maksudkan adalah tanggap terhadap persoalan baik masalah sekolah, lingkungan termasuk lingkungan sekolah dan masalah sosial serta keadaan alam. Pada saat penelitian ini dilaksanakan dunia termasuk Indonesia sedang dilanda wabah pandemi covid 19. Peneliti mencoba mengarahkan seberapa cerdas atau tanggap mereka dengan lingkungan sebagai bentuk implementasi karakter kecerdasan. Sebagian besar mereka menyadari dan tanggap terhadap bahaya virus corona 19 sehingga himbauan dari pemerintah harus ditaati yaitu melaksanakan protocol kesehatan. Dari hasil observasi memang siswa tidak ada yang melanggar protocol kesehatan, tidak melakukan kerumunan di sekolah maupun di luar sekolah.

\section{Karakter Demokratis dan Keiklasan}

Karakter demokratis dan keiklasan, nilai karakter demokratis dan keiklasan dalam geguritan Ni Dyah Tantri telah diterapkan dengan baik oleh masing-masing siswa kelas XI Akuntansi SMK TI Bali Global Singaraja dalam keseharian di kelasnya. Hal ini ditunjukkan dengan nilai karakter demokratis dan keiklasan yang diimplementasikan oleh siswa sebesar $81,75 \%$ (baik). Dari hasil wawancara dengan siswa yang bersangkutan yaitu menunjukkan bahwa masing-masing individu siswa telah menerapkan sikap demokratis dan keiklasan. Karakter demokratis dan keiklasan merupakan umum yang dimiliki oleh kebanyakan orang. Mereka mengimplementasikan sikap ini ketika di kelas pembelajaran berlangsung dengan mengadakan diskusi kelompok, jika beberapa pelajaran ada yang belum dimengerti mereka segera diskusikan agar tercapai pemecahan masalahnya. Berani berbendapat ketika ada pemilihan kepala sekolah, ketua osis maupun ketua kelas. Rela atau iklas membantu teman yang sedah kesusahan saat menerima pembelajaran dengna membantu menjelaskannya. Selain itu sikap ini diimplemetsaikan di sekolah, sikap ini juga diterapkan di masyarakt dan kelurga 
Jurnal Widya Sastra Pendidikan Agama Hindu, Vol 4, No. 2, 2022

ISSN: 2656-7466

dengan ikut serta bermusyawarah ketika ada permasalahan yang harus dipecahkan dalam masyarkat maupun keluarga.

\section{Karakter Ketangguhan dan Kerja keras}

Karakter ketangguhan dan kerja keras, nilai karakter ketangguhan dan kerja keras dalam geguritan Ni Dyah Tantri telah diterapkan dengan sangat baik oleh masing-masing siswa kelas XI Akuntansi SMK TI Bali Global Singaraja dalam keseharian di kelasnya. Hal ini ditunjukkan dengan nilai karakter ketangguhan dan kerja keras yang diimplementasikan oleh siswa sebesar 92,66\% (sangat baik). Karakter ketangguhan dan kerja keras yang dimiliki oleh seorang siswa sangatlah penting karena dengan sikap inilah yang menjadi dasar bagi siswa tersebut menempuh pendidikan dimana seorang siswa harus bekerja keras dalam memenuhi tanggung jawabnya sebagai siswa dengan belajar giat dan tekun, datang lebih awal ke sekolah apabila sedang bertugas piket dan melaksanakan tugasnya sebaik mungkin, Tidak bolos atau mangkir dari sekolah tanpa alasan tidak jelas, Mengerjakan PR di rumah sebaik mungkin dan dikumpul sesuai dengan jadwal yang disepakati, Apabila melakukan kesalahan, mengakui kesalahan tersebut kemudian meminta maaf dan mencari solusi terbaik sebagai wujud tanggung jawab, mengerjakan tugas dengan senang hati, dapat berkosentrasi pada semua pembelajaran. Sikap ketangguhan dan kerja keras diimplemetasikan di masyarakat yaitu dengan ikut dalam kegiatan bergotong royong memperbaiki selokan yang mampet, membantu sesama saat mereka tertimpa musibah

\section{Karakter Patrotik dan Cinta Damai Serta Toleransi}

Karakter patrotik dan cinta damai serta toleransi, nilai karakter patrotik dan cinta damai serta toleransi dalam geguritan Ni Dyah Tantri telah diterapkan dengan sangat baik oleh masing-masing siswa kelas XI Akuntansi SMK TI Bali Global Singaraja dalam keseharian di kelasnya, masyarakt maupun keluarga. Hal ini ditunjukkan dengan nilai karakter patrotik dan cinta damai serta toleransi yang diimplementasikan oleh siswa sebesar 96\% (sangat baik). Karakter Patriotik, Cinta Damai dan Toleransi merupakan umum dimiliki oleh kebanyakan orang. Dari hasil wawancara dengan siswa terkait bagaimana mereka mengimplementasikan karakter dalam kehidupan di sekolah maupun luar sekolah, mereka merespon bahwa karakter tersebut terlaksana tanpa perencanaan karena sudah menjadi hal sangat biasa bagi siswa. Karakter patriotik, cinta damai serta toleransi adalah kewajiban siswa untuk melaksanakan karena tuntutan dari sekolah, masyakat, keluarga, Bangsa dan Negara. Penanaman sikap patriotik melalui upacara bendera setiap hari senin dan siswa menjadi petugas upacara. Kewajiban seorang siswa ketika kesekolah memakai pakaian seragam yang rapi, rambut tidak diwarnai dan tidak mencoret-coret tembok sekolah. Sikap patriotik juga diimplementasikan di masyarakat dengan ikut menjaga kerukunan didalam berkehidupan di masyarakat, mencintai produk dalam negeri. Sikap toleransi ini juga umum dimiliki oleh kebanyakan orang termasuk di lingkungna sekolah yaitu tidak membuat gaduh susasana sekolah, menghargai perbedaan pendapat teman, menghargai teman yang beribadah dan tidak membedakan suku, ras, dan agama dalam menjali pertemanan atau kehidupan di sekolah, keluarga dan masyarakat sehingga terciptanya kedamaian dan kesejahteraan.

\section{KESIMPULAN}

Nilai karakter yang terdapat pada geguritan Ni Dyah Tantri sebanyak tujuh nilai karakter dan terimplementasi secara klasikal sebesar $85.18 \%$ (sangat baik). 
Implementasi dilihat dari masing-masing nilai karakter ditemukan seperi data ini: 1) cinta kasih 92,75\% (Sangat Baik),, 2) disiplin dan kesetiaan 87,33\% (Sangat Baik), 3) bersahabat dan komunikatif 71,5\% (Cukup), 4) kecerdasan 90, 54\% (Sangat Baik), 5) demokratis dan keiklasan 81,75\% (Baik), 6) ketangguhan dan kerjas 92,66\% (Sangat Baik), 7) patriotik dan cinta damai serta toleransi $96 \%$ (Sangat Baik). Hasil penelitian direkomendasikan kepada para pendidik informal, formal (guru) di SMK TI Bali Global Singaraja dapat mentransfer nilai-nilai karakter dalam geguritan Ni Dyah Tantri lebih baik lagi untuk menunjang capaian lulusan yang berkualitas.

\section{DAFTAR PUSTAKA}

Agastia, Ida Bagus Gede. 1980. "Geguritan Sebuah Bentuk Karya Sastra Bali" (Makalah untuk Sarahsehan Sastra Daerah Pesta Kesenian Bali II di Denpasar). Tamtam.

Aryani, Ni Wayan. 1987. Analisis Struktur dan Nilai Pendidikan dam Geguritan

Astriani, Kiki. 2014. Nilai-nilai Pendidikan Karakter yang Terkandung dalam Bhagavadgitha. STKIP AH. Singaraja.

Awanita, Made. 2008 Membentuk Kepribadian Anak dalam Kandungan (Sebuah Implementasi Keluarga) Perspektif Agama Hindu. Surabaya, Paramita.

Ayu. Jati Jayanti Made. 2016. Analisis Nilai Pendidikan Dalam Geguritan Basur". STKIP AH. Singaraja

Ghoni, Muhamad Djunaidi. 1982. Nilai Pendidikan. Surabaya: Usaha Nasional. Rosdakarya.

Moleong, L. J. 2010. Metodologi Penelitian Kualitatif, Bandung: Remaja

Moleong, Lexy J. 2012. Metodologi Penelitian Kualitatif, Bandung: Remaja Rosdakarya.

Rupa. I Ketut. 2010. Geguritan Sucita Analisis Nilai dan Aspek Sosial Pendidikan Agama Hindu). IHDN Denpasar. Thesis.
Ratna.
2005.
Teori
Hegemoni
Gramsci.

https://pusatbahasaalazhar.com/pesona-puisi/teori-hegemoni.

Ratna Syifa'a Rachmahana. 2008. Psikologi Humanistik dan Aplikasinya dalam Pendidikan. Jurnal Kepolisian Vol. I (1)

Suastini, Ni Nyoman. 2008. Eksistensi Tirtha Sanjiwani dalam Upacara Yadnya

di Desa Pakraman Lebah, Desa Sekumpul, Kecamatan Sawan, Kabupaten Buleleng (Kajian Fungsi-Makna Religius). IHDN Denpasar; Thesis.

Suweja, I Nyoman. Analisis Nilai Pendidikan Karakter pada Satua Ni Diah

Tantri. Fakultas Pendidikan Bahasa dan Seni. IKIF PGRI. Bali.

Sugiyono. (2012). Metode Penelitian Kuantitatif Kualitatif Dan R\&D. Bandung: C.V Alfabeta.

Sugiyono. (2011). Metode Penelitian Pendidikan (Pendekatan Kuantitatif, Kualitatif, danR\&D). Bandung: C.V Alfabet.

Sutopo. H.B. 2006. Metodelogi Penelitian Kualitatif. Surakarta: Penerbit Universitas Sebelas Maret.

Titib, I Made. Menumbuhkan Pendidikan dan Budi Pekerti pada Anak (Perspektif Agama Hindu). Pustaka Bali Post. Denpasar.

Teeuw, A. 1984. Sastra dan Ilmu sastra: Pengantar Teori Sastra. Jakarta: Pustaka Jaya.

Tanu, I Ketut. Isu-isu Kontemporer Pendidikan Agama Hindu di Sekolah Dasar (Perspekif Kritis). Sari Khayangan Indonesia. Denpasar.

Tinggen. I Nengah. 1982. Aneka Sari. Sekolah Pendidikan Guru Singaraja 
Jurnal Widya Sastra Pendidikan Agama Hindu, Vol 4, No. 2, 2022

ISSN: 2656-7466

Poerwadarminta, W.J.S. 1976. Kamus Umum Bahasa Indonesia, Balai Pustaka, Jakarta.

Palmer, Richard E. 2005. Hermeneutika. Teori Baru Mengenai Interpretasi. Pustaka Pelajar: Yogyakarta

Wiana, I Ketut. 1997. Cara Belajar Agama Hindu yang Baik. Yayasan Dharma Naradha, Denpasar. 